\section{„Polnische Bibliothek" Karla Dedeciusa. Literatura między polityką kulturalną a praktyką wydawniczą}

Paweł Zajas
Artykuł powstał w ramach realizacji projektu badawczego $\mathrm{nr} 2017 / 25 / \mathrm{B} /$ $\mathrm{HS} 2 / 00109$, sfinansowanego ze środków Narodowego Centrum Nauki.

TEKSTY DRUGIE 2020, NR 6, S. 321-341

DOI: 10.18318/td.2020.6.19 | ORCID: 0000-0001-6041-297X

1

Zainicjowana przez Niemiecki Instytut Kultury Polskiej w Darmstadt, sfinansowana przez Fundację im. Roberta Boscha i wydawana przez oficynę Suhrkamp Verlag „Polnische Bibliothek" stanowi po dzień dzisiejszy unikatową w swojej skali próbę prezentacji literatury polskiej na niemieckojęzycznym rynku wydawniczym. W 50 tomach, które ukazywały się w latach 1982-2000, zaprezentowano rozwój piśmiennictwa od średniowiecza do połowy $\mathrm{XX}$ wieku.

W literaturze przedmiotu zwykło się podkreślać polityczno-kulturalne znaczenie serii przy jednoczesnej krytyce jakoby niewystarczającego zaangażowania Suhrkampa. Hedwig Nosbers ujęła tę kwestię na krótko przed zakończeniem serii w następujących słowach:

Na początku lat 8o., w czasach, gdy Polska z racji wydarzeń politycznych była w Republice Federalnej Niemiec tematem codziennych dyskusji, a nowo

\section{PawełZajas -}

profesor na Wydziale Anglistyki Uniwersytetu im. Adama Mickiewicza w Poznaniu oraz badacz stowarzyszony (research fellow) na University of Pretoria (RPA). W obszarze jego zainteresowań znajdują się kwestie dotyczące transferu oraz socjologii literatury. 
powstały Niemiecki Instytut Kultury Polskiej spotykał się z powszechnych wsparciem, wydawnictwo liczyło - z uwagi na minimalne ryzyko finansowe, gwarantowane subwencją Fundacji Boscha, oraz niewielki własny nakład pracy - na ciekawy, a być może nawet intratny projekt. Zaangażowanie znacznie osłabło w momencie, gdy okazało się, iż żywione wobec projektu nadzieje spełniły się zaledwie wobec kilku tytułów, a nie całej serii, natomiast w polityce wydawnictwa pojawiły się odmienne priorytety. Dziś „Polnische Bibliothek” - do jej zakończenia brakuje zaledwie kilku tomów - nie odgrywa większej roli w programie Suhrkampa. [...]

Jeśli wziąć pod uwagę dość wstrzemięźliwą postawę wydawnictwa w kwestii propagowania polskich tytułów - być może z wyjątkiem książek Stanisława Lema oraz pojedynczych książek Zbigniewa Herberta - można niemalże wyrazić zdziwienie, że kilka tomów Biblioteki mimo wszystko okazało się sukcesem. ${ }^{1}$

Powyższy cytat wydaje się problematyczny z co najmniej dwóch powodów. Po pierwsze, badaczka spogląda na kulisy powstania Biblioteki tylko i wyłącznie z perspektywy jej pomysłodawcy, Karla Dedeciusa; zgodnie z jego przekazem Suhrkamp otrzymywał "gotowy produkt", który jednak nie uzyskał należytej rangi w polityce wydawnictwa ${ }^{2}$. Po drugie, skutkiem tej rozpowszechnionej, choć nie do końca (jak się przekonamy) trafnej narracji jest dysymulacja procesów i konfliktów towarzyszących powstaniu „Polnische Bibliothek". Kontrowersje te nie pełnią wyłącznie funkcji historycznoliterackiej anegdoty. Dają nam one wgląd w niewidoczne z zewnątrz mechanizmy selekcji przekładów literatury polskiej w ramach programu liczącego się na niemieckim rynku komercyjnego wydawnictwa.

Niniejszy szkic jest poświęcony „anatomii” „Polnische Bibliothek”. Po omówieniu historycznego i polityczno-kulturalnego tła serii, próbuję udzielić odpowiedzi na pytanie o nośność argumentacji przedstawionej przez Dedeciusa, a następnie przejętej przez historyków książki. Analiza, oparta w przeważającej części na niepublikowanej korespondencji wydawniczej, ma dwojaki cel: z jednej strony kładzie nacisk na historiograficzny opis nieznanych dotąd procesów transferu literatury polskiej do niemieckiego obszaru

1 H. Nosbers Polnische Literatur in der Bundesrepublik Deutschland 1945/49 bis 1990. Buchwissenschaftliche Aspekte, Harrassowitz, Wiesbaden 1999, s. 131, 133.

2 Tamże, s. 133. 
językowego, z drugiej zaś wychodzi naprzeciw potrzebie należytej konceptualizacji tego typu zjawisk. Za metodologiczną ramę posłużyła kategoria Histoire Croisée, w tym konkretnym przypadku zaadoptowana do badania procesu produkcji przekładu. Punktem wyjścia są tu: działalność wszystkich zaangażowanych podmiotów, powstałe konflikty oraz propozycje ich rozwiązania ${ }^{3}$. "Splataniu” $i$ „krzyżowaniu" poddane zostały racje i przekonania poszczególnych aktorów pola wydawniczego i polityczno-kulturalnego w odniesieniu do prezentacji literatury polskiej w Niemczech. Powstała w ten sposób przestrzeń argumentacyjna oferuje wgląd w historię powstania serii, której od samego początku towarzyszyły rozbieżne oczekiwania.

\section{2}

Koncepcja „Polnische Bibliothek” odwoływała się do tradycji stosunkowo dobrze zakorzenionej w XX-wiecznej historii niemieckiego rynku wydawniczego. W 1902 roku Julian Marchlewski wraz z Alexandrem Helphandem założyli oficynę mającą publikować postępowe dzieła z obszaru literatur słowiańskich i skandynawskich. W ciągu dwóch lat jej działalności ukazało się niemal 50 tytułów polskich, rosyjskich oraz nordyckich autorów. Odmienne interesy wspólników doprowadziły jednak do zaprzestania działalności w 1905 roku $^{4}$

W kontekście projektu Dedeciusa na obszerniejszą wzmiankę zasługuje przede wszystkim zainicjowany w 1916 roku przez Aleksandra Guttrego i Władysława Augusta Kościelskiego projekt „Polnische Bibliothek”, która w latach 1918-1919 ukazywała się w monachijskim Georg Müller Verlag. W trzech działach - I. Dzieła z zakresu historii i historii kultury, II. Wspomnienia, osobliwości i edycje klasyków oraz III. Powieści, nowele, dramaty i poezja - wydano zaledwie siedem z ponad trzydziestu zaplanowanych tomów (m.in. dzieła Adama Mickiewicza, Wiktora Gomulickiego, Stanisława Augusta Poniatowskiego, Stanisława Przybyszewskiego i Władysława Łozińskiego). Owa pierwsza „Polnische Bibliothek” była z jednej strony niewątpliwie efektem koniunktury na przekłady literatur z terenów okupowanych oraz objętych działaniami wojennymi ${ }^{5}$, z drugiej zaś miała znaczenie propagandowe. $\mathrm{Na}$

3 M. Werner, B. Zimmermann Vergleich, Transfer, Verflechtung. Der Ansatz der Histoire croisée und die Herausforderung des Transnationalen , "Geschichte und Gesellschaft" 2001 No. 28, s. 617.

4 H. Nosbers Polnische Literatur, s. 29-32.

5 Por. P. Zajas Literatura światowa w czasie Wielkiej Wojny (1914-1918). Jan Paweł Kaczkowski jako aktor 
rynku pojawiła się jednakże zdecydowanie zbyt późno, w okresie, gdy trwały rokowania pokojowe. $\mathrm{Z}$ powodu przedwczesnej śmierci edytora $\mathrm{w}$ grudniu 1917 roku, zakończenia działań wojennych oraz powojennej inflacji prawa autorskie do poszczególnych tytułów zostały sprzedane innym domom wydawniczym. Aleksander Guttry wraz z żoną Ireną podejmowali w późniejszym okresie regularne próby reaktywacji Biblioteki w Georg Müller Verlag, wydawca jednak każdorazowo reagował odmownie, motywując swoją decyzję napiętą sytuacją polityczną ${ }^{6}$.

W tym kontekście należy odnotować, że powojenne plany kontynuacji „Polnische Bibliothek” wpisywały się w programowe założenia polityki kulturalnej prowadzonej przez Towarzystwo Wspierania Polskiej Sztuki wśród Obcych (TOSSPO) utworzone w 1926 roku z inicjatywy sanacyjnego rządu?. Symptomatyczne, że próby reaktywowania Biblioteki podjęto ponownie po podpisaniu w styczniu 1934 roku deklaracji polsko-niemieckiej o niestosowaniu przemocy - deklaracji, która zapoczątkowała jednocześnie fazę pozornego zbliżenia w stosunkach kulturalnych ${ }^{8}$. Trzy dni po podpisaniu umowy z Rzeszą Guttry, występując w funkcji wiceprzewodniczącego TOSSPO, przedłożył w MSZ „Plan propagowania polskiej kultury w Niemczech”, sądząc że „obecnie sprawa ta nabrała szczególnej aktualności. Niewątpliwie teraz, po zawarciu paktu, zainteresowanie współczesną kulturą polską się zwiększy". W porozumieniu z Reichsschrifttumskammer stworzono „plan propagowania literatury", w którym obok wystaw książki, numerów poświęconych literaturze polskiej i niemieckiej w czasopismach oraz odczytów o obu literaturach istotną rolę miała odgrywać „Polnische Bibliothek”. Prowadzone w 1934 roku pertraktacje z narodowosocjalistycznym wydawnictwem Etthofen-Verlag zakończyły się niepowodzeniem.

Trzy lata później podjęto kolejną próbę, tym razem we współpracy z berlińską galerią sztuki Wolfganga Gurlitta. Subwencje warszawskiego MSZ

polsko-belgijsko-niemieckiego transferu literackiego „,Pamiętnik Literacki” 2015 Z. 2, s. 191-222.

6 Georg Müller Verlag do Aleksandra Guttrego, 13.1.1928, Deutsches Literaturarchiv Marbach (DLA).

7 P. Zajas Pénétration poétique. Zur deutschen und polnischen "Kunst- und Kulturpropaganda” (1916-1939), w: In officio amicitiae. Andreas Lawaty dem Grenzgänger und Freund zum 65. Geburtstag, hrsg. K. Ruchniewicz, S. Troebst, M. Zybura, Neisse Verlag, Dresden 2018, s. 573-582.

8 Zob. K. Pryt Befohlene Freundschaft. Die deutsch-polnischen Kulturbeziehungen 1934-1939, Fibre, Osnabrück 2010.

9 Aleksander Guttry do MSZ, 29.1.1934, Archiwum Akt Nowych (ANN). 
obejmowały honoraria dla autorów i tłumaczy, a także gwarancję odbioru 200 egzemplarzy każdego dzieła. Guttry pisał:

Nie ulega wątpliwości, że w ten sposób systematycznie ujęte propagowanie kultury i literatury polskiej przyniosłoby olbrzymie korzyści nie tylko na terenie Niemiec, lecz i we wszystkich krajach, dokąd język niemiecki dociera i gdzie czytują książki niemieckie, a więc m.in. w całej Skandynawii, Holandii, w państwach bałtyckich, Ameryce itd. ${ }^{10}$

W ciągu kilku miesięcy intensywnych pertraktacji między wydawcą, ambasadą polską w Berlinie, Ministerstwem Spraw Zagranicznych oraz TOSSPO powstał program serii, w której znalazły się m.in. zredagowane przez Guttrego listy Chopina oraz biografia kompozytora pióra Juliusza Kadena-Bandrowskiego, przeglądowe prace o polskiej sztuce autorstwa Tadeusza Seweryna i Mieczysława Tretnera, powieści Ferdynanda Goetla, Jarosława Iwaszkiewicza, Marii Kuncewiczowej, Zofii Nałkowskiej i Jana Parandowskiego oraz wybór nowel Stefana Żeromskiego. Choć w przedsięwzięcie zaangażowano utworzone w 1938 roku i działające pod egidą berlińskiego MSZ Stowarzyszenie Niemiecko-Polskie, niezbędną zgodę Ministerstwa Propagandy udało uzyskać się dopiero w styczniu 1939 roku. W lipcu 1939 roku Guttry otrzymał wieńczącą przygotowawcze prace przesyłkę. Zawierała ona prospekt reklamowy, który informował subskrybentów, że jesienią ukażą się pierwsze tomy „Polnische Bibliothek”, oraz brakujące, opłacone przez MSZ przekłady utworów Iwaszkiewicza (Panny z Wilka, Młyn nad utrata), Nałkowskiej (Granica) i Goetla (Kar-Chat).

\section{3}

Cel przyświecający działalności Aleksandra Guttrego, którego realizację przekreślił wybuch wojny, został podjęty ponownie przez Karla Dedeciusa w połowie lat 6o. ubiegłego wieku. Sporządzony przez Dedeciusa w 1967 roku „Memoriał w sprawie utworzenia niemiecko-słowiańskiej biblioteki wraz z centrum tłumaczy" dokumentuje jednocześnie koncepcyjne początki powstałego w 1980 roku Niemieckiego Instytutu Kultury Polskiej w Darmstadt. Do licznych zadań planowanej instytucji należało m.in. 
1. zbieranie - z zachowaniem czytelnego podziału - literatury pięknej pisanej w językach słowiańskich, przy jednoczesnym ograniczeniu kolekcji do XX w. [...]; 2. gromadzenie przekładów tych literatur na język niemiecki; 3. gromadzenie przekładów literatury niemieckiej na języki słowiańskie; 4. gromadzenie czasopism literackich wydawanych w krajach słowiańskich; 5. gromadzenie niemieckojęzycznych publikacji na temat literatur słowiańskich; 6. opracowywanie tychże materiałów [...]; 7. wydawanie w późniejszym okresie rocznika [...]; 8. współpraca z Niemiecką Biblioteką Narodową, uniwersyteckimi wydziałami slawistyki, Stowarzyszeniem Księgarzy Niemieckich, niemieckimi wydawnictwami oraz Akademie für Sprache und Dichtung; 9. nawiązanie współpracy z aktywnymi tłumaczami z języków słowiańskich; 10. utworzenie grup roboczych dla literatury rosyjskiej, czeskiej oraz polskiej; 11. współpraca [...] z instytutami germanistyki, względnie organizacjami zrzeszającymi tłumaczy w krajach słowiańskich (celem odpowiedniego wyboru i przekładu dzieł literatury niemieckiej); 12. fachowe wsparcie udzielane młodym tłumaczom [...]; 13. współpraca między niemieckimi i słowiańskimi wydawnictwami. ${ }^{11}$

Rozległy geograficzny zasięg działalności postulowanej w dokumencie należy tłumaczyć pozycją, jaką Dedecius zajmował w ówczesnym zachodnioniemieckim polu wydawniczym. W trzech najważniejszych oficynach - Suhrkamp, Hanser-Verlag oraz S. Fischer-Verlag - oferował swoje usługi jako „doradca w obszarze literatur wschodnioeuropejskich"12 i przedstawiał propozycje przekładów literatury polskiej, czeskiej, rosyjskiej i jugosłowiańskiej. Choć z S. Fischer-Verlag prowadził w tym czasie negocjacje dotyczące utworzenia „serii literatur słowiańskich” ${ }^{3}$, to równoległa korespondencja z Suhrkampem dowodzi, że zależało mu przede wszystkim na instytucjonalnym umocowaniu transferu literatury polskiej do Republiki Federalnej Niemiec ${ }^{14}$. Ze względów politycznych plan Dedeciusa nie uzyskał wówczas

11 Karl Dedecius Denkschrift zum Plan der Gründung einer deutsch-slawischen Bibliothek mit Übersetzerzentrum, niedatowana notatka [1967], DLA.

Peter Härtling do Karla Dedeciusa, 25.05.1967, DLA. DLA. 
wsparcia zachodnioniemieckiego MSZ ${ }^{15}$, tłumacz zdołał jednak zachować pozycję monopolisty: kiedy w 1970 roku socjolog Juliusz Stroynowski, wyemigrowawszy do RFN, planował utworzenie w Suhrkampie „Biblioteki Słowiańskiej”, Dedecius nakłonił dyrektora oficyny, Siegfrieda Unselda, by odrzucił projekt ${ }^{16}$, po czym siedem lat później sam przedłożył wydawnictwu plan serii „Polonica”"

Historyczny moment był niewątpliwie korzystny: gest Willy'ego Brandta pod pomnikiem Bohaterów Getta w grudniu 1970 roku symbolizował przełom w stosunkach dyplomatycznych między RFN a PRL. Wzajemne inicjatywy kulturalne mogły odtąd liczyć w Bonn na oficjalne wsparcie organizacyjne i finansowe. W kontekście polityczno-kulturalnym niepoślednią rolę odgrywał również ratyfikowany w sierpniu 1975 roku w Helsinkach akt końcowy Konferencji Bezpieczeństwa i Współpracy w Europie, w którym 35 szefów rządów zobowiązało się m.in. do zintensyfikowania wymiany w obszarze kultury, edukacji i informacji. Idee przedstawione w memoriale Dedeciusa z 1967 roku przybrały znany dziś kształt Niemieckiego Instytutu Kultury Polskiej. Finansowego wsparcia udzielił Wydział Kultury zachodnioniemieckiego MSZ, a burmistrz Darmstadt, Winfried Sabais, przekazał na potrzeby nowo powstałej instytucji reprezentacyjną willę, zaprojektowaną przez tworzącego w stylu secesji austriackiego architekta Josepha Marię Olbricha. Instytut rozpoczął działalność w marcu 1980 roku $^{18}$.

Koncepcja wzmiankowanej serii „Polonica” - „wyjątkowej i wzorcowej prezentacji literatury narodowej"19 , która niedługo potem miała ujrzeć świa-

15 A. Blumenfeld Der Anfang. Zum 10-jährigen Bestehen des Deutschen Polen-Instituts, w: Deutsches Polen-Institut. Arbeitsbericht, Hrsg. A. Lempp, Deutsches Polen-Institut, Darmstadt 1991, s. 8.

16 P. Zajas „Wie lieben ja die Polen..." Zum Forschungspotenzial des Siegfried Unseld Archivs im Hinblick aufden polnisch-deutschen Literaturtransfer, "Zeitschrift für Slawistik” 2018 No. 1, s. 16-21.

17 W kontekście początków "Polnische Bibliothek" należy również przypomnieć zainicjowaną W 1968 roku przez Klausa Staemmlera w Claassen-Verlag „Bibliotheca Polonica”. Seria nie spotkała się jednak z zainteresowaniem publiczności, a wydawnictwo szybko zrezygnowało z jej kontynuacji; zob. K.A. Kuczyński Klaus Staemmler. Tłumacz i popularyzator literatury polskiej w Republice Federalnej Niemiec, "Acta Uniwersitatis Lodzensis. Folia Litteraria” 1981 nr 1, s. 125; H. Nosbers Polnische Literatur, s. 144-145; K. Sauerland Meine ersten Begegnungen mit Karl Dedecius, "OderÜbersetzen” 2018 No. 9-10, s. 44.

K. Dedecius Ein Europäer aus Lodz. Erinnerungen, Suhrkamp, Frankfurt/M. 2006, s. 315-320. DLA. 
tło dzienne jako „Polnische Bibliothek” - powstawała równolegle z organizacją Instytutu. Choć zarówno jej kształt, jak i miejsce w ramach programu Suhrkampa pozostawały na razie nieokreślone, Unseld już na wstępie sygnalizował gotowość realizacji tego "niezwykle pięknego przedsięwzięcia”, które „zachowa swoją wagę przez kolejne dziesięciolecia”20. Pisał do Dedeciusa: „Co Schlegel i Tieck uczynili dla Szekspira, Ty czynisz dla Polski”21. Podczas trzech kolokwiów skupiających tłumaczy i polonistów dokonano pierwszej selekcji tytułów oraz określono ich objętość. Biblioteka miała „za pomocą wysokiej jakości przekładów udostępniać szerokiej, wykształconej niemieckiej publiczności literaturę polską, legitymującą się europejską rangą i aspirującą do kanonu Weltliteratur. Poszczególni autorzy i ich dzieła winni przyczynić się do lepszego zrozumienia polskiej historii i kultury"22. W ramach 25 planowanych tomów przewidywano pierwotnie antologie poświęcone określonym epokom, gatunkom lub tematom, prezentacje pięciu poetów oraz pięciu prozaików, a także „materiały źródłowe na temat polskiej mentalności i historii myśli" (sprawozdania z podróży, listy, dzienniki, eseje) ${ }^{23}$.

Fundacja Roberta Boscha zaakceptowała wniosek o finansowanie projektu, umowa między Suhrkampem a Fundacją została podpisana w grudniu 1981 roku i gwarantowała pokrycie kosztów produkcji, przekładu oraz częściowe dofinansowanie honorariów dla redaktorów poszczególnych tomów. Tym samym pierwsze tytuły - Die Dichter Polens (Polscy poeci), Das Junge Polen. Literaturder Jahrhundertwende (Młoda Polska. Literatura przełomu wieków), Kordian i cham Leona Kruczkowskiego, wybór poezji Czesława Miłosza oraz Reise nach Warschau (Podróż do Warszawy) Joachima Christiana Friedricha Schulza mogły ukazać się już w 1982 roku. W lipcu 1985 roku Fundacja podjęła decyzję o sfinansowaniu kolejnych 25 tomów. W październiku 1987 roku Siegfried Unseld wygłosił przemówienie podczas uroczystości odbywającej się w darmstadzkiej Oranżerii z okazji ukazania się 25 tomu „Polnische Bibliothek”:

W moim dzienniku odnotowałem symbolicznie: „Rok 1982 był rokiem recesji". Podjęcie projektu z pewnością nie nastawionego na zyskowną

Siegfried Unseld do Karla Dedeciusa, 9.06.1978, DLA.

Tamże.

Deutsches Polen-Institut Ergebnisprotokoll zum 3. Polonisten-Übersetzer-Kolloquium am 19./20.12.1980 in Darmstadt, 7.01.1981, DLA.

Karl Dedecius do Siegfrieda Unselda, 6.03.1983, DLA. 
sprzedaż było zatem aktem odwagi. 24 września tego roku, a więc pięć lat później, ukazał się Kot w mokrej trawie, opowiadania Kornela Filipowicza składające się na 25 tom serii. Pięć lat, pięć tomów rocznie, 25 tomów w sumie, zaplanowanych i zrealizowanych - taka zgodność z programem należy do rzadkości. Liczba 25 kojarzy się ze srebrnym jubileuszem. Idea małżeństwa jako symbol relacji łączącej autora z wydawcą bynajmniej nie jest nowa. Martin Walser napisał ostatnio, że to osobliwe małżenstwo, przypominające harem: wielu autorów i tylko jeden wydawca. Ale w przypadku „Polnische Bibliothek” mamy do czynienia z prawnym unikatem: małżeństwo trojga, zawarte między Niemieckim Instytutem Kultury Polskiej, Fundacją Roberta Boscha i wydawnictwem Suhrkamp. Zgodnie z obowiązującym prawem tego rodzaju związek jest karalny.Troje partnerów zawarło go jednak równocześnie, trudno zatem określić który z nich jest bigamistą. Chyba że wskażemy Karla Dedeciusa, który przed ponad pięciu laty, po utworzeniu Instytutu, zebrał nas w celu powołania do życia „Polnische Bibliothek”"

\section{4}

Za fasadą okolicznościowej przemowy oraz 50 tomami Biblioteki kryją się momentami niezwykle gwałtowne różnice zdań między „małżonkami”. Wgląd w korespondencję pozwala przede wszystkim zauważyć, że Instytut oraz Fundacja przypisywali powstającej serii cele, które niekoniecznie odpowiadały profilowi oficyny oraz przyjętym w niej praktykom. Z perspektywy Fundacji Biblioteka miała głównie wymiar polityczno-kulturalny, stanowiła „wyjątkową próbę literackiego pośrednictwa w równie wyjątkowej pod względem historycznym relacji między Niemcami a Polakami"25. Dedecius posługiwał się wielokrotnie kategorią „reprezentatywności”: Biblioteka winna była przekazywać „podstawową wiedzę dotyczącą historii literatury polskiej”26. Z kolei dla wydawnictwa kluczowa była nie argumentacja h i s t o r y c z n o literacka, lecz jakość oraz rynkowa wartość tekstów.

Zobowiązania partnerów określone zostały pierwotnie w sposób następujący: Niemiecki Instytut Kultury Polskiej występował jako „inicjator”

\footnotetext{
24 Siegfried Unseld Bedenke, bevor du denkst, 30.10.1987, DLA.

25 Ulrich Bopp do Siegfrieda Unselda, 17.05.1993, DLA.

26 Karl Dedecius do Siegfrieda Unselda, 6.03.1983, DLA.
} 
programu, Karl Dedecius był odpowiedzialny za „opiekę redakcyjną oraz kontrolę jakości tłumaczeń", Suhrkamp zaś miał „produkować subwencjonowane tomy"27. Wydawca, nie godząc się z przypisaną mu rolą drukarza, regularnie komentował proces selekcji tekstów. I tak na przykład zauważał, że choć Listy do Marysieńki Sobieskiego stanowią „uroczy dokument” historii kultury, to na zachodnioniemieckim rynku tego typu książki będą zaledwie ozdobą i jako takie winny być „bardzo starannie dozowane”. Stanisław Ignacy Witkiewicz był w opinii Unselda ważnym przedstawicielem modernizmu, jednak przekład jego tekstów mógł liczyć na niewielką grupę odbiorców. Edytor kwestionował ponadto nadmiar antologii przy jednoczesnym niedoborze współczesnych powieści wśród pierwszych tomów serii $^{28}$.

Gdy Dedecius chciał wydać Rozkazy, mowy i listy Józefa Piłsudskiego, wskazując na jego „wciąż żywą legendę”, znaczenie postaci dla Solidarności oraz „błyskotliwy styl polskiej, romantyczno-barokowej proweniencji”, redaktorka Suhrkampa Elisabeth Borchers pytała: „Czy to są kryteria obowiązujące dla «Polnische Bibliothek»?"29. Przedłożony wydawnictwu jeszcze w 1980 roku przekład wybranych wierszy Norwida Borchers odrzuciła nie tylko z powodu archaicznego stylu, ale przede wszystkim z uwagi na fakt, że konfrontował on niemieckiego czytelnika ze zbyt egzotycznym przykładem nieznanej mu XIX-wiecznej literatury polskiej, uniemożliwiając tym samym „obiektywną" ocenę tekstu ${ }^{30}$. Weto wydawcy dotyczyło również tekstów, których objętość przekraczała przewidziane w kalkulacji 500 stron (m.in. powieści Bolesława Prusa, Henryka Sienkiewicza i Józefa Mackiewicza).

W przypadku Mackiewicza powody nieopublikowania jego książek w ramach serii miały charakter zarówno natury literackiej, jak i politycznej. Autor żył na emigracji w Monachium od 1945 do śmierci w 1985 roku. Publikował w rozmaitych czasopismach i tomach zbiorowych, dając wyraz zaniepokojeniu brakiem gotowości Niemiec Zachodnich do obrony Europy przed komunizmem; jego zdaniem antynazistowska i antykomunistyczna

\footnotetext{
27 Vertrag über Publikations-Zuschuss, 30.12.1981, DLA. Siegfried Unseld do Karla Dedeciusa, 04.02.1983, DLA. Karl Dedecius do Siegfrieda Unselda, 22.06.1983; E. Borchers, notatka wewnętrzna, 1.08.1983, DLA. 
polityka historyczna były postawami konkurencyjnymi ${ }^{31}$. W przekładzie na język niemiecki ukazało się pięć książek Mackiewicza, dwie ostatnie - Lewa Wolna (1963) oraz Nie trzeba głośno mówić (1969) - nie znalazły wydawcy, co autor przypisywał pogłębiającej się izolacji reprezentowanych przez siebie poglądów i cenzurze politycznej poprawności. Protektorem pisarstwa Mackiewicza w RFN stał się Gotthold Rhode, pochodzący z Poznania znawca problematyki Wschodu i spraw polskich. Jako członek prezydium Niemieckiego Instytutu Kultury Polskiej w Darmstadt zaproponował on w 1984 roku włączenie do serii powieści Nie trzeba głośno mówić, której obszerne fragmenty sam przetłumaczył.

U Tomasza Mianowicza, który monachijskiemu okresowi życia pisarza poświęcił szkic, lektura recenzji wydawniczych wywołała „rumieniec zażenowania”, jako że „rzekomi specjaliści od literatury polskiej zupełnie nie znali wydarzeń będących historycznym tłem powieści"32. Mianowicz nie referuje wzmiankowanych sądów, nie jest jednak prawdą, że opinia przesądzająca o odrzuceniu książki wyszła spod pióra polonisty omawiającego dzieło z uwagi na jego miejsce w systemie literatury polskiej. Autorem recenzji był Wolfram Schäfer - redaktor odpowiedzialny w latach 1981-1987 za redakcję poszczególnych tomów „Polnische Bibliothek”. Schäfer czytał fragmenty przekładu, kierując się nie dokumentacyjną i historyczną wartością książki, lecz jej potencjalnymi walorami literackimi. Te wydały mu się nikłe. Zaznaczał, że choć wydane w Niemczech w latach 40. i 50. tłumaczenia utworów Mackiewicza bez wątpienia trafiały w polityczne oczekiwania odbiorców (destalinizacja, krytyka komunizmu), to przedłożona „powieść przypominająca reportaż $[. .$.$] wypełnia wprawdzie, patrząc z perspektywy historycznej, pew-$ ną lukę, jednak nie wydaje się ona wzbogacać literatury. [...] Dochodzi w niej do głosu zaangażowany i zainteresowany polityką publicysta, a nie poeta"33.

Nadesłane do wydawnictwa apele Kazimierza Brandysa, Jerzego Giedroycia i Czesława Miłosza pozostały bez wpływu na ostateczną decyzję o niewłączeniu do serii Nie trzeba głośno mówić. Tymczasem w Darmstadt postanowiono, by w miejsce negatywnie ocenionej przez Suhrkamp książki

31 A. Lawaty Józef Mackiewicz, Gotthold Rhode i „niemiecki czytelnik”. Powinowactwo z wyboru i mielizny recepcji w Niemczech, w: tegoż Intelektualne wizje i rewizje w dziejach stosunków polsko-niemieckich XVIII-XXI wieku, Universitas, Kraków 2015, s. 323. dia, szkice, dokumenty" 2002/2003 nr 56, s. 183. 
wznowić wydaną jeszcze w 1957 roku w niemieckim przekładzie powieść Kontra (Tragödie an der Drau). Tym razem recenzja Wolframa Schäfera była znacznie surowsza. Pisał:

W tym obszernym dziele mamy do czynienia z dziennikarskim śledztwem/sprawozdaniem wojennym dotyczącym obszarów okupowanych przez Niemcy na Wschodzie w latach 1941/42. Całkowicie nieprzejrzyste nagromadzenie aktów sabotażu, egzekucji, odezw podziemia, wiadomości prasowych, rozkazów, zarządzeń, memoriałów i tajnych sprawozdań zostało połączone z niezliczonymi miejscami akcji na tyłach frontu, trzy razy większą liczbą osób i przysługujących im tytułów oraz statystykami dotyczącymi armii i toczonych bitw $[\ldots]^{34}$

Schäfer wyliczał literackie mankamenty książki, w jego opinii „chaotycznej niczym partyzancka walka na Białorusi": brak narracyjnej perspektywy, ekonomii językowej, konfrontowanie czytelnika z bezlikiem dokumentów, fikcyjnych materiałów oraz przypadkowych rozmyślań natury religijnej i filozoficzno-kulturowej. Również polityczna wymowa książki spotkała się ze zdecydowaną reakcją redaktora. Sygnalizowane w tekście zrozumienie dla działań kierującego „operacją Barbarossa” Alfreda Rosenberga, wyrażana przez protagonistów pogarda dla bolszewizmu oraz ich ocena szans polsko-nazistowskiego sojuszu antykomunistycznego wydały się Schäferowi „raczej niesmaczne, niż przekonujące". Tezy Mackiewicza musiały przypominać redaktorowi wysuwane od początku lat 8o.zastrzeżenia Ernsta Noltego wobec "demonizowania” fenomenu narodowego socjalizmu. Choć kontrowersyjny artykuł O przeszłości, która nie chce przeminać - w którym Nolte twierdził, że nazizm stanowił swojego rodzaju odpowiedź na bolszewizm, a zbrodnie i eksterminacje dokonywane w Rosji Radzieckiej i w ZSRR były chronologicznie wcześniejsze od hitlerowskiego ludobójstwa ${ }^{35}$ - ukazał się w czerwcu 1986 roku i nie mógł mieć bezpośredniego wpływu na opinie Schäfera, to samą temperaturę debaty, jaką Nolte wywołał, można uznać za ogólny probierz dla tematów (nie)akceptowanych w tamtym czasie w publicznym dyskursie zachodnioniemieckim. Jeśli „Polnische Bibliothek” miała być literacko wartościową inicjatywą polityczno-kulturalną, to Kontra Mackiewicza została

34 Tenże, 5.11.1985, DLA.

35 E. Nolte O przeszłości, która nie chce przeminqć, w: Historikerstreit. Spór o miejsce III Rzeszy w historii Niemiec, red. M. Łukasiewicz, Aneks, Londyn 1990, s. 65-69. 
odrzucona przez Suhrkamp jako estetycznie bezwartościowe politicum. Niepowodzeniem zakończyła się również próba publikacji wyboru opowiadań z tomu Fakty, przyroda, ludzie (1984), zostały one bowiem odrzucone przez nowego redaktora, Bernda Schwibsa, z powodu widocznych w tekście uprzedzeń antysemickich oraz słabej jakości przekładu ${ }^{36}$.

Józef Mackiewicz nie był jedynym autorem, którego teksty zakwestionowali redaktorzy. Z ostrą oceną ze strony Wolframa Schäfera spotkał się również wydany w 1947 roku w Rzymie Dziennik podróży do Austrii i Niemiec Jerzego Stempowskiego. Abstrahując od nie najlepszej jakości przekładu, Schäfer uznał tekst za pozbawiony elementarnej logiki w budowaniu świata przedstawionego, zawierający niespójne obserwacje, nierzadko niekorespondujące z prawdą historyczną. „Zagmatwany” język sprawiał, że od początku miało się wrażenie, jakby autor przedstawiał „wydarzenia z 1842 roku”. Zirytowany redaktor pisał w zjadliwym tonie:

Gdy orientujemy się, że odmalowano tutaj obraz powojennych Niemiec, możemy z niedowierzaniem kręcić głową, że tego właśnie autora wybrano, aby przedstawić niemieckiemu czytelnikowi, jak jego kraj jest postrzegany przez sąsiada. Wystarczy porównać precyzyjnie napisane i pełne informacji Podróże Inflantczyka z Rygi do Warszawy i po Polsce wlatach 1791-1973 Fryderyka Schulza z tymi upiększonymi bredniami zwapniałego intelektualisty, by zobaczyć różnice poziomu w podejściu do sprawy. Stempowski z pewnością jest twórcą zasłużonym, ale tego tekstu, który dla współczesnego czytelnika jest po prostu nie do przyjęcia, nie można włączyć do „Polnische Bibliothek", ${ }^{37}$

Podczas gdy z jednej strony wydawnictwo kwestionowało jakość tekstów i przekładów, z drugiej Unseld dopominał się o książki, których nieobecność na listach sporządzonych przez Dedeciusa była jego zdaniem trudna do uzasadnienia: dlaczego brakuje Witolda Gombrowicza? Czy „Polnische Bibliothek" jest do pomyślenia bez mickiewiczowskiego Pana Tadeusza? Gdzie

A. Lawaty JózefMackiewicz..., s. 360-367.

Wolfram Schäfer, 3·3.1983. Wspomnienia Joachima Christopha Friedricha Schulza Reise nach Warschau ukazały w "Polnische Bibliothek" w 1982 roku jako czwarty tom serii. Polski przekład, autorstwa Józefa Ignacego Kraszewskiego, został opublikowany w 1870 roku i wznowiony W 1953 roku nakładem wydawnictwa Czytelnik. Niemiecki przekład niemieckiego dziennika Stempowskiego ukazał się W 1998 roku. 
się podział Rękopis znaleziony w Saragossie Potockiego, który, wydany uprzednio w należącym do Suhrkampa Insel-Verlag, mógłby zostać bez trudu włączony do serii w ramach umowy licencyjnej? Ostatni punkt był przedmiotem częstych konfliktów, z brakiem zrozumienia ze strony wydawnictwa spotykały się bowiem propozycje przekładu książek, których autorzy byli już obecni w programie oficyny. Przykładowo, czy konieczne było finansowanie tłumaczenia kolejnych opowiadań Jana Józefa Szczepańskiego, skoro trzy wcześniej zniemczone tytuły zalegały w magazynach Suhrkampa? Przecież włączenie ich do Biblioteki mogłoby tchnąć w nie nowe życie ${ }^{38}$.

Nieliczne istotnie merytoryczne recenzje prasowe, poddające ocenie kompozycję Biblioteki, wydają się potwierdzać krytyczną intuicję pracowników wydawnictwa. Jochen Halbey na marginesie lektury przygotowanej przez Dedeciusa antologii Die Dichter Polens. Hundert Autoren vom Mittelalter bis heute (Polscy poeci. Stu autorów od średniowiecza do dnia dzisiejszego) oraz kilku innych tomów pisał:

Nie, nie wszyscy zostali uwzględnieni. W rubryce „barok” znajdziemy za to pogromcę Turków króla Jana Sobieskiego, przy ekspresjonizmie legendarnego dyktatora Piłsudskiego, w końcu, rzecz oczywista, niejakiego Karola Wojtyłę. Niektórzy królowie, dyktatorzy i papieże potrafią zapewne sprawnie posługiwać się piórem, czy jednak oznacza to, że automatycznie należy ich zaliczyć do grona wybitnych autorów, podczas gdy dla twórców ważniejszych, niebędących królami, dyktatorami ani papieżami, zabrakło miejsca? Całość [...] sprawia wrażenie dość chaotyczne i przypomina broszury państwowych biur podróży: zapowiadanych atrakcji brak, są za to niespodzianki. [...] Kogo interesują długie na ponad dwieście stron listy króla Jana Sobieskiego do żony? Czy nie odgrzewa się tu potajemnie mitu Polski jako zbawcy chrześcijańskiego Zachodu? Być może zresztą listy te są „pod względem historyczno-kulturowym i literackim znaczące" (informacja z okładki), wystarczyłoby jednak umieścić kilka w antologii poświęconej literaturze barokowej. [...] Jakie będą dalsze losy „Polnische Bibliothek”? Czy doczekamy się w końcu dzieł wielkich polskich poetów, obiecanych „klasyków”, prezentowanych w całości, a nie fragmentów poupychanych w antologiach i wypisach? [...] Czy w Bibliotece pojawią się znaczący powojenni autorzy, nasi współcześni, czy też poprzestanie ona na zbiorze wspomnień 
Piłsudskiego oraz dramatów (Hiob) i poezji Karola Wojtyły w celu budującej prezentacji liturgicznej historii narodu? ${ }^{39}$

Także w „Die Zeit” - tygodniku, którego redaktorka naczelna, Marion Gräfin Dönhoff, pełniła funkcję prezydenta-założyciela Niemieckiego Instytutu Kultury Polskiej - pojawiały się głosy krytyczne:

Pierwszych czternaście tomów przypomina na razie kolorowy dywan: tu antologia, tam dziennik, tu wznowienie wcześniej wydanej powieści, tam zbiór aforyzmów, tu listy króla do żony, tam pedagogiczne pisma lekarza. [...] Wydawcom marzyła się seria stu tytułów z podziałem na dziesięć działów tematycznych. [...] Niektórzy z nas znajdą wśród nich prawdziwe skarby, inni odkryją przede wszystkim bolesne luki. ${ }^{40}$

\section{5}

Tymczasem konflikty towarzyszące pracy przy kolejnych tomach nie ustawały. Mimo finansowych gwarancji ze strony Fundacji nierentowne tytuły stanowiły problem. Podczas gdy Dedecius podkreślał wagę wydawanych dzieł dla „porozumienia między narodami”, wydawczyni przywoływała sprawozdania działu kolportażu, które "nie tuszują i nie upiększają słabych wyników sprzedaży, wręcz dumnie je podkreślają, by udowodnić, że mimo wszystko mamy odwagę wydawać tego typu literaturę"41. Dokumenty archiwalne wskazują na luki w metodyce transferu literatury: ponieważ raporty finansowe wydawnictw niezwykle rzadko są przedmiotem zainteresowania literaturoznawców, rynkowy wymiar procesu transferu dóbr symbolicznych pozostaje niespełnionym dezyderatem badawczym. Ta konstatacja pokazuje jednocześnie, w jak dużym stopniu dyskurs literaturoznawczy, hołdujący ideałom estetycznej autonomii, ignoruje ekonomiczną materialność tekstów, a tym samym wciąż na nowo wpisuje się w wypracowaną w ramach tradycji marksistowskiej narrację dotyczącą domniemanego normatywnego

39 J. Halbey Panopticum Polonicum oder Hoffnung der Besiegten, "Frankfurter Rundschau” 28.8.1984, s. 9 .

40 L. von Zitzewitz Nachbar Polen. Literarische Kleinodien in der "Polnischen Bibliothek", „Die Zeit” 1985 No. 12 , s. 56. 
konfliktu między polem kultury a wolnym rynkiem ${ }^{42}$. Analiza korespondencji dotyczącej historii powstania „Polnische Bibliothek” stawia nas przed wyzwaniem funkcjonalnej integracji archiwaliów, będących śladem zarówno estetycznego, jak i rynkowego wartościowania tekstów literackich.

Najlepiej sprzedającym się tomem Biblioteki była antologia pism Janusza Korczaka Das Kind lieben (Miłość do dziecka), której popularność wiązała się zapewne zarówno z tragicznym losem pedagoga, jak i z podejmowaną przez niego tematyką. Deficytowe okazały się z kolei prezentacje polskiej poezji. Wydane w 1982 roku w nakładzie 1200 egzemplarzy wiersze Czesława Miłosza znalazły do czerwca 1987 roku zaledwie 1100 nabywców; Tadeusz Różewicz (Gedichte, 1983) i Wisława Szymborska (Hundert Freuden, 1986) nie przekroczyli pułapu 600 sprzedanych egzemplarzy. W magazynach wydawnictwa zalegały również pozostałe tytuły, m.in. Popiót $i$ diament Jerzego Andrzejewskiego (770 sprzedanych egz.), Ozimina Wacława Berenta (500 egz.), Szalona lokomotywa Stanisława Ignacego Witkiewicza (870 egz.), opowiadania Jarosława Iwaszkiewicza (69o egz.), powieść Sól ziemi, eseje i wiersze Józefa Wittlina (wydane pod tytułem Die Geschichte vom geduldigen Infanteristen - 690 egz.) czy Pamiątki Soplicy Henryka Rzewuskiego (530 egz.) ${ }^{43}$. Unseld notował: „Pozostaje pytanie, jak długo jeszcze wydawnictwo będzie mogło ponosić straty związane z Biblioteką, jej magazynowaniem oraz związaną z nią administracją" ${ }^{44}$. Celem częściowej przynajmniej kompensacji deficytu wydawca podjął decyzję o wznowieniu nielicznych dochodowych tytułów nie w ramach Biblioteki, lecz w formie wydania kieszonkowego. Wiązało się to nie tylko z koniecznością wypłacenia Fundacji umownego odszkodowania, lecz było również przedmiotem kolejnego sporu między Unseldem a Dedeciusem. I tak w serii „suhrkamp taschenbuch" wydano m.in. Warschauer Tagebuch Kazimierza Brandysa, ilustrowany zbiór aforyzmów Bedenke, bevor du denkst oraz Reise nach Warschau Schulza.

W „małżeństwie trojga” coraz częściej dochodziło do niesnasek. Władze Fundacji raz po raz wyrażały żal, że pozycja Biblioteki w polityce programowej Suhrkampa nie odpowiada jej ,jakości i polityczno-kulturalnej wadze” i domagały się podniesienia literatury polskiej do rangi geograficznego priorytetu

42 J. Griem Ökonomische Materialität von Literatur, w: Handbuch Literatur \& Materielle Kultur, Hrsg. S. Scholz, U. Vedder, de Gruyter, Berlin \& Boston 2018, s. 153. 
(Länderschwerpunkt) ${ }^{45}$. Poruszano również problem niedostępności/braku dodruków poszczególnych tomów. Niemiecki Instytut Kultury Polskiej reagował na raporty dotyczące sprzedaży „bezradnością”, sygnalizując, że „optymalnie wykorzystał wszelkie znajdujące się w jego mocy siły i środki" ${ }^{46}$. Irytację okazywali także współpracownicy Suhrkampa. Unseld z niemałym zdziwieniem przyjął wiadomość o podjętym przez Dedeciusa planie publikacji siedmiotomowej Panorama der polnischen Literatur des 20. Jahrhunderts, która miała ukazywać się w latach 1996-2000 w zuryskim Amman-Verlag. Na marginesie korespondencji z tłumaczem notował: „Jak to możliwe?! W sąsiedztwie pięćdziesięciotomowej Biblioteki, stosownie reprezentującej XX stulecie, pojawia

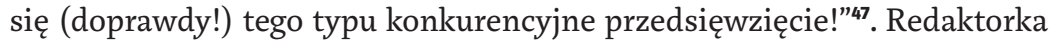
Elisabeth Borchers sekundowała wydawcy:

Polska znajduje się w sytuacji nadzwyczajnej. Jej literatura będzie obecna na niemieckojęzycznym rynku w formie pięćdziesięciu tomów. I jakby tego było mało, kolejna publikacja - siedem razy po siedemset stron, i tylko XX wiek. Pytam, gdzie na świecie mamy do czynienia z czymś podobnym? Nawet Polacy [...] nie są aż tak rozrzutni. Przykro mi to pisać, ale takie zachowanie jest irytujące, aroganckie. ${ }^{48}$

Fakt, że w ramach tak szeroko zakrojonego projektu dochodziło do nieporozumień, nie powinien dziwić. W kontekście niniejszych rozważań istotne są przede wszystkim rozbieżne funkcje przypisywane Bibliotece. Po kilku latach działalności przedstawiciele Fundacji wciąż pisali o „wymianie kulturowej” i "polityczno-kulturalnym znaczeniu serii”, dla Karla Dedeciusa liczyła się reprezentatywność w prezentacji literatury narodowej, natomiast wydawnictwo utyskiwało na deficytowy interes, który dodatkowo, jak notował Unseld w 1984 roku, „wyniszczał" regularny program oficyny w obszarze literatury polskiej".

Uwaga wydawcy znajduje potwierdzenie w wydawniczych statystykach. W latach 1980-2000 wśród 150 polskich tytułów (liczonych wraz ze

\footnotetext{
45 Peter Payer do Siegfrieda Unselda, 3.02.1989, DLA. 
wznowieniami) 50 przypada na „Polnische Bibliothek”. Kolejnych 50 książek to literatura fantastyczna i science fiction, którą Suhrkamp zainteresował się na początku lat 70. Znaczna część tych publikacji (44 tytuły) to przekłady twórczości Stanisława Lema. Lem po raz pierwszy zagościł w Suhrkampie w 1973 roku, szybko awansował do miana autora, który jak żaden inny uosabiał „ducha czasu, wyczulonego na kwestie naukowo-prognostyczne"50, jednak w latach 8o. ofertę jego dzieł ograniczono do licencjonowanych reprintów. Pozostałe sześć tytułów to zapomniani klasycy polskiej fantastyki: Jerzy Żuławski, Antoni Słonimski i Stefan Grabiński. Po 1980 roku wydano również nieliczne nowości Zbigniewa Herberta i Wisławy Szymborskiej, na próżno jednak szukać w programie Suhrkampa przełomowych odkryć w obszarze współczesnej polskiej beletrystyki.

W tym względzie interesująca jest zawartość zbioru recenzji towarzyszących „Polnische Bibliothek”, stanowiącego część archiwum wydawnictwa. W trzech obszernych teczkach udokumentowano przede wszystkim, oprócz skrupulatnie zebranych omówień serii, historię niemieckiego sukcesu Andrzeja Szczypiorskiego, który po ukazaniu się przekładu powieści Poczatek (Die schöne Frau Seidenman, 1988) został gwiazdą premierowego odcinka legendarnego „Kwartetu literackiego”, a telewizyjna laudacja wygłoszona przez Marcela Reicha-Ranickiego zaowocowała w krótkim czasie sprzedażą na poziomie stu tysięcy egzemplarzy. W Suhrkampie z niemałą zazdrością śledzono powstały wokół pisarza szum medialny, a odręczne notatki na gromadzonych tekstach prasowych podkreślały pełnioną przez Szczypiorskiego funkcję „duchowego ambasadora" Polski w Niemczech.

\section{6}

Z perspektywy Fundacji Roberta Boscha finansowanie „Polnische Bibliothek” miało tę samą rangę co pozostałe międzynarodowe projekty realizowane w obszarze ochrony zdrowia czy edukacji; wspólnym mianownikiem było każdorazowo pojednanie z sąsiednimi narodami ${ }^{51}$. Wsparcie, którego Fundacja udzieliła w późniejszych latach projektowi „Tschechische Bibliothek”

50 M. Schwartz "Eine Vision anderer Zeiten und Welten." Der Osten Europas und die „Phantastische Bibliothek", w: Kulturtransfer und Verlagsarbeit. Suhrkamp und Osteuropa, Hrsg. D. Kemper, P. Zajas, N. Bakshi, Wilhelm Fink, Paderborn 2019, s. 107.

51 Beziehungen zu den Ländern Mittel-und Osteuropas 1974-1999, Robert Bosch Stiftung, Stuttgart 1999, s. IX. 
(1999-2007, 33 tomy) oraz „Türkische Bibliothek” (2005-2010, 20 tomów), definiowane było jako „wkład w powstanie stosownego, rozumnego obrazu tożsamości naszych sąsiadów i przyjaciól" ${ }^{\prime 2}$. W oficjalnych komunikatach przyznawano również, że chodzi w tym przypadku przede wszystkim o inwestycję polityczno-kulturalną:

Biblioteki te - podobnie jak finansowane przez nas programy dla lektorów, tutorów i managerów kultury - są jednocześnie wyrazem wzajemnego zrozumienia dla owocnych stosunków kulturalnych. Gdy inwestujemy w odpowiedni wizerunek kultury krajów partnerskich w Niemczech, możemy oczekiwać, że nasza oferta kulturalna będzie tam traktowana z takim samym szacunkiem, ciekawością i sympatią. ${ }^{53}$

Również dla Dedeciusa podstawową funkcją transferu literatury było porozumienie między historycznie zwaśnionymi narodami. Przekład definiował jako „pośrednie narzędzie polityki"54. Archiwalna rekonstrukcja dowodzi jednak, że ocena „Polnische Bibliothek” nie może ograniczać się do jej funkcji polityczno-kulturalnej, uwzględnić należy także mechanizmy pola wydawniczego. Na podstawie dostępnych dokumentów trudno udzielić przekonującej odpowiedzi na pytanie o powody, dla których Siegfried Unseld zdecydował się wydawać Bibliotekę. Suhrkamp publikował nie książki, lecz autorów - ta dewiza określająca politykę oficyny obowiązuje do dziś. Cztery lata przed oficjalną premierą serii Unseld pisał:

Taką właśnie maksymą kierowali się wydawcy literatury w ścisłym znaczeniu słowa.W swojej pracy stawiali nie na pojedynczy, obiecujący tytuł, lecz na dzieło konkretnego autora [...]. Wydawnictwo rozwija się dzięki takim autorskim dziełom. Książki związanych z nim autorów są niczym słoje drzewa, z biegiem czasu w organiczny sposób powstaje to, co zwykliśmy nazywać profilem lub wizerunkiem wydawnictwa. ${ }^{55}$

52 P. Theiner Stiftungszweck Völkerverständigung. Robert Bosch und die Robert Bosch Stiftung, Verlag Stiftung \& Sponsoring, Stuttgart 2009, S. 15. Tamże.

K. Dedecius Im Namen einer besseren Zukunft: Ansätze der Gemeinsamkeit in der deutsch-polnischen Literatur, "Jahresring. Beiträge zur deutschen Literatur und Kunst der Gegenwart" 1965 No. $65 / 66$, s. 303 .

S. Unseld Der Autor und sein Verleger, Suhrkamp, Frankfurt/M. 1978, s. 36. 
Z tak zarysowanej perspektywy „Polnische Bibliothek” jawi się niczym wyłom w skądinąd konsekwentnej polityce Suhrkampa. Przywoływana na wstępie teza o słabnącym zaangażowaniu Unselda w promocję serii winna być rozpatrywana w szerszym kontekście ambicji oficyny, która w latach 60. i 70 była postrzegana jako kuźnia awangardowej literatury i teorii. Wymowna etykieta Suhrkamp Culture autorstwa George'a Steinera (1973) oznaczała wyczucie ducha czasu, znaczącą pozycję w polu europejskiej historii intelektualnej. Można wyrazić przypuszczenie, że Biblioteka stanowiła obietnicę nadrobienia zaległości w obszarze literatury polskiej (Herbert był jedynym polskim pisarzem o europejskiej randze na stałe związanym z wydawnictwem). Być może liczono na "gwałtowny przełom" ${ }^{56}$, jaki się dokonał w przypadku literatury latynoamerykańskiej, która w połowie lat 70. zajęła centralne miejsce w zagranicznym programie Suhrkampa. Pokładane w Bibliotece nadzieje nie ziściły się. Niezależnie od wykładni „kultury Suhrkampa” zdefiniowanej przez Steinera "specyficznie polskie" teksty do niej nie pasowały ${ }^{57}$, natomiast nadzieja na pozyskanie prestiżowych nazwisk okazała się płonna.

Wśród Länderschwerpunte aktualnie zdefiniowanych na stronie internetowej wydawnictwa nie znajdziemy Polski. „Polska specyfika”, przeciwko której swego czasu protestował Unseld, ukrywa się pod hiperonimem „Europa Wschodnia". Autorzy tacy jak Wojciech Kuczok, Andrzej Stasiuk czy Michał Witkowski wydają się pasować do recepcyjnego schematu oscylującego między uniwersalizmem a egzotyką. Forma ich narracji jest „europejska”, jednakże świat przedstawiony w pożądany sposób kontrastuje z przestrzenią Europy Zachodniej. Osteuropa pozostaje, jak informował paratekst wydanej w 2012 przez Suhrkamp antologii Das wilde Leben. East Side Storys, „położonym tuż obok nas Dzikim Zachodem. Wszystko jest tam bardziej surowe, gwałtowne, ekscytujące. A opowieści leżą na ulicy"58.

Siegfried Unseld Chronik, 15.09.1976, DLA.

57 Siegfried Unseld do Karla Dedeciusa, 05.01.1981, DLA.

58 K. Raabe Das wilde Leben. East Side Storys, Suhrkamp, Frankfurt/M. 2012. 


\section{Abstract}

\section{Paweł Zajas}

ADAM MICKIEWICZ UNIVERSITY (POZNAŃ),

UNIVERSITY OF PRETORIA (SOUTH AFRICA)

Karl Dedecius' "Polnische Bibliothek": Literature Between Cultural Policy and Publishing Practice

The "Polnische Bibliothek" - launched by the Polish Cultural Institute in Darmstadt, cofunded by the Robert Bosch Foundation and published by Suhrkamp Verlag - represents a unique attempt to introduce Polish literature to the German-language book market. Zajas examines the project's historical, political and institutional context. Drawing on unpublished correspondence between contributors he highlight understudied processes pertaining to the transfer of Polish literature into the German-language cultural field and addresses the need for a conceptualisation of such phenomena. His methodological framework is based on the notion of histoire croisée, adapted in this case to the study of a translation's production. The point of departure is the work of the many individuals involved, their conflicts and their attempts to solve them.

\section{Keywords}

German publishing field, Karl Dedecius, Polnische Bibliothek, Suhrkamp Verlag 